\title{
KAJIAN KUALITAS AIR DALAM EVALUASI PENGEMBANGAN PERIKANAN DI WADUK IR. H. DJUANDA, JAWA BARAT
}

\author{
Didik Wahju Hendro Tjahjo"1) dan Sri Endah Purnamaningtyas'1) \\ 1) Peneliti pada Loka Riset Pemacuan Stok Ikan, Jatiluhur-Purwakarta
}

Teregristrasi I tanggal: 3 September 2007; Diterima setelah perbaikan tanggal: 25 Januari 2008; Disetujui terbit tanggal: 4 Maret 2008

ABSTRAK

Budi daya ikan di Waduk Ir. H. Djuanda $\left(A=8.300\right.$ ha, $Z_{\max }=95 \mathrm{~m}$, dan $\left.Z=36,5 \mathrm{~m}\right)$ berkembang sangat pesat, sehingga berdampak pada penurunan kualitas air. Tujuan penelitian ini adalah untuk mengevaluasi kualitas air bagi kepentingan perikanan dan mengidentifikasi sumber tekanan tertinggi di Waduk Ir. H. Djuanda. Pengambilan data dilakukan setiap bulan dan tahun 2004 sampai dengan 2006. Pengamatan kualitas air dilakukan dengan metode pengambilan contoh air secara horisontal dan vertikal. Hasil penelitian menunjukkan bahwa sumber utama degradasi kualitas air adalah bahan organik yang berasal dari Waduk Cirata. Distribusi vertikal oksigen terlarut di perairan menunjukkan ada stratifikasi dengan kedalaman epilimnion yang sangat tipis. Berdasarkan pada analisis kandungan fosfat dan nitrogen, waduk ini telah mengalami perubahan dari eutrofik (tahun 2004) menjadi hipereutrofik (tahun 2005 dan 2006). Degradasi tersebut cenderung meningkat seiring dengan peningkatan jumlah unit karamba jaring apung yang dikembangkan di Waduk Cirata dan Waduk Ir. H. Djuanda. Kondisi ini menunjukkan bahwa pengembangan kegiatan budi daya dalam karamba jaring apung telah melampaui daya dukung dan cenderung mencemari perairan. Upaya mengatasi degredasi tersebut dapat dilakukan dengan 2 cara, yaitu 1) mengurangi usaha budi daya ikan dalam karamba jaring apung di Waduk Ir. H. Djuanda dan Cirata dan 2) menebarkan jenis ikan yang mampu memanfaatkan plankton secara efektif.

KATAKUNCI: $\quad$ kualitas air, degradasi, perikanan, Waduk Ir. H. Djuanda

ABSTRACT: $\quad$ Study of water qualities for fisheries development in Ir. H. Djuanda Reservoir, West Java. By: Didik Wahju Hendro Tjahjo and Sri Endah Purnamaningtyas

Development of fish culture in Ir. H. Djuanda Reservoir has been expanded very fast, so it might cause the degradation of water qualities. The aims to evaluated water quality for fisheries purpose and identify the primary pressure source in Ir. H. Djuanda Reservoir. The data were collected every month during year of 2004 to 2006. Water sampling was done by vertical and horizontal. The result indicates that the primary source degradation of water qualities was organic materials from Cirata Reservoir. Stratification of dissolved oxygen in the water column indicates with very thin epilimnion layer. Based on phosphate and N-compuonds analysis, Ir. H. Djuanda Reservoir was changed from eutrophic in year 2004 to hipereutrophic in year 2005 and 2006. The degradation tends to increase with developing floating cage unit numbers in Cirata and Ir. H. Djuanda Reservoir. This condition shows that the development of fish culture in floating cage seems have be over the carry capacity of reservoir and tend to spread the pollution in the water. It effort suggest that the would two ways, i.e. 1) decrease of fish culture activities using be done refering floating cages in Ir. H. Djuanda and Cirata Reservoir and 2) stocking of fish species which are capable to utilized the plankton effectively.

KEYWORDS: $\quad$ water quality, degradation, fisheries, Ir. H. Djuanda Reservoir

\section{PENDAHULUAN}

Sistem waduk kaskade di Sungai Citarum (Waduk Djuanda, Cirata, dan Saguling) dimulai dengan pembangunan Waduk Ir. H. Djuanda (tahun 1967) terletak pada ketinggian $116 \mathrm{~m} \mathrm{dpl}(\mathrm{A}=8.300 \mathrm{ha}$, $Z_{\text {maks }}=95 \mathrm{~m}, Z=36,4 \mathrm{~m}$ ) dan pengembangan garis pantai 5,96 (Tjahjo, 1986), serta luas catchment area 4.500 $\mathrm{km}^{2}$ (Loebis \& Syariman, 2007). Secara administrasi, waduk ini terletak di Kabupaten Purwakarta, Jawa Barat dan secara geografis terletak pada $6^{\circ} 29^{\prime} \mathrm{LS}-6^{\circ} 41^{\prime} \mathrm{LS}$ dan $107^{\circ} 18^{\prime} \mathrm{BT}-107^{\circ} 24^{\prime} \mathrm{BT}$. Secara morfologi, Waduk
Ir. H. Djuanda dikelilingi oleh pegunungan kapur yang agak gundul (Sarnita, 1981).

Waduk Ir. H. Djuanda adalah waduk serbaguna dengan fungsi utama adalah pembangkit listrik tenaga air, bahan baku air minum, irigasi dan pencegah banjir, serta fungsi tambahan untuk perikanan, transportasi, dan pariwisata.

Pengembangan budi daya ikan dalam karamba jaring apung yang diizinkan di Waduk Ir. H. Djuanda 
berdasarkan pada S.K. Bupati Purwakarta No.06/2000 adalah sebatas 2.100 unit. Oleh karena itu, Waduk Ir. H. Djuanda mempunyai potensi pengembangan budi daya ikan yang tinggi, maka pertumbuhan budi daya tersebut berkembang sangat pesat. Pada tahun 2005 jumlah karamba jaring apung mencapai 4.577 unit dan tahun 200615.000 unit. Perkembangan yang pesat tersebut sangat berdampak pada penurunan kualitas air baik untuk kehidupan dan perkembangan usaha perikanan, bahan baku air minum maupun terhadap peralatan pembangkit listrik tenaga air. Bahkan sebagian besar jenis ikan asli Sungai Citarum sudah sangat jarang ditemukan di perairan ini, seperti lalawak (Barbodes bramoides), genggehek (Mystacoleucus marginatus), lempuk (Ompok bimaculatus), tawes (Barbonymus gonionotus), walange (Lais hexanema), dan wader (Puntius binotatus).

Tekanan terhadap ekosistem Waduk Ir. H. Djuanda tersebut semakin bobot, karena waduk tersebut menempati posisi paling hilir antara lain 3 waduk kaskade di Sungai Citarum. Karakteristik ekosistem Waduk Ir. H. Djuanda sangat dipengaruhi oleh kondisi ekosistem Waduk Cirata dan Saguling di bagian hulu. Jumlah karamba jaring apung di Waduk Saguling pada tahun 2005 telah mencapai 7.272 unit, dan di Waduk Cirata mencapai 39.690 unit, padahal jumlah yang diizinkan di Waduk Cirata berdasarkan pada S.K. Gubernur Jawa Barat No.41/2002 hanya 12.000 unit. Tujuan penelitian ini adalah untuk mengevaluasi kualitas air untuk kepentingan perikanan dan mengidentifikasi sumber tekanan tertinggi yang mempengaruhi penurunan kualitas air di Waduk Ir. $\mathrm{H}$. Djuanda.

Tabel 1. Deskripsi stasiun pengamatan Table 1. Description of observation stations

\section{BAHAN DAN METODE}

Kualitas air secara umum menunjukkan mutu atau kondisi air yang dikaitkan dengan suatu kegiatan atau keperluan tertentu. Pemantauan kualitas air ini dilakukan dengan pencuplikan berkala contoh air dengan metode terstratifikasi horisontal dan vertikal (Nielsen \& Johnson, 1985). Secara vertikal, contoh diambil dengan menggunakan Kemmerer Botle sampler pada 5 kedalaman $0,5 \mathrm{~m}$ (permukaan 0 sampai dengan $1 \mathrm{~m}$ ), $2 \mathrm{~m}$ ( 1 sampai dengan $3 \mathrm{~m}$ ), dan dasar perairan). Pengambilan contoh dilakukan di 11 stasiun pengamatan dengan mempertimbangkan karakteristik perairan waduk secara umum (Kimmel \& George dalam Ryding \& Rast, 1989), yaitu (I) Parung Kalong, (II) Sodong, (III) Bojong, (IV) Jamaras, (V) Kerenceng, (VI) Baras Barat, (VII) Cilalawi, (VIII) PDAM, (IX) Taroko, (X) Karamba, dan (XI) DAM (Tabel 1 dan Gambar 1). Stasiun pengamatan tersebut dapat dikelompokkan menjadi 2 kelompok, yaitu alur Sungai Citarum dan Sungai Cilalawi. Alur Sungai Citarum terdiri atas stasiun pengamatan I, II, III, IV, V, VI, dan $\mathrm{XI}$, sedangkan alur Sungai Cilalawi terdiri atas stasiun pengamatan VII, VIII, IX, X, dan XI. Pengambilan contoh air dilakukan pada tanggal 20 setiap bulan selama tahun 2004 sampai dengan 2006.

Parameter kualitas air yang diamati secara in situ meliputi kecerahan, $\mathrm{pH}$, oksigen terlarut, dan karbon dioksida bebas, sedangkan parameter kualitas air yang dianalisis di laboratorium meliputi ammonium, nitrat, dan orto fosfat. Metode yang digunakan dalam analisis kualitas air tersebut tertera dalam Tabel 2. Data yang diperoleh dianalisis secara deskriptif dalam bentuk grafik.

\begin{tabular}{|c|c|c|c|c|c|}
\hline \multicolumn{2}{|c|}{$\begin{array}{l}\text { Stasiun pengamatan/ } \\
\text { Observation station }\end{array}$} & \multirow{2}{*}{$\begin{array}{l}\text { Kisaran/ } \\
\text { Range } \\
\mathrm{Z}_{\max }\end{array}$} & \multirow{2}{*}{$\begin{array}{l}\text { Deskripsi pemanfaatan lahan/ } \\
\text { Description of zona using }\end{array}$} & \multirow{2}{*}{$\begin{array}{c}\text { Masukkan sungai } \\
\text { utama/ } \\
\text { Input of main river }\end{array}$} & \multirow{2}{*}{$\begin{array}{c}\text { Kelompok/ } \\
\text { Group }\end{array}$} \\
\hline No. & $\begin{array}{l}\text { Nama/ } \\
\text { Name }\end{array}$ & & & & \\
\hline $\mathrm{I}$ & Parung Kalong & $3-5$ & Sawah tadah hujan & Sungai Citarum & Alur Citarum \\
\hline II & Sodong & $4-8$ & Ladang, pemukiman & Sungai Citarum & Alur Citarum \\
\hline III & Bojong & $4-8$ & Ladang, pemukiman & Sungai Citarum & Alur Citarum \\
\hline IV & Jamaras & $6-14$ & Ladang & Sungai Citarum & Alur Citarum \\
\hline $\mathrm{V}$ & Kerenceng & $15-28$ & Ladang & Sungai Citarum & Alur Citarum \\
\hline VI & Baras Barat & $28-53$ & Ladang & Sungai Citarum & Alur Citarum \\
\hline VII & Cilalawi & $9-14$ & Ladang, sawah tadah hujan & Sungai Cilalawi & Alur Cilalawi \\
\hline VIII & PDAM & $22-34$ & Ladang, PDAM & Sungai Cilalawi & Alur Cilalawi \\
\hline IX & Taroko & $34-53$ & $\begin{array}{l}\text { Ladang, pemukiman, industri, } \\
\text { karamba jaring apung }\end{array}$ & Sungai Cilalawi & Alur Cilalawi \\
\hline$x$ & Karamba & $47-60$ & Ladang, karamba jaring apung & Sungai Cilalawi & Alur Cilalawi \\
\hline $\mathrm{XI}$ & DAM & $60-90$ & Karamba jaring apung & $\begin{array}{l}\text { Pertemuan dua } \\
\text { sungai }\end{array}$ & Genangan utana \\
\hline
\end{tabular}


Kelimpahan fitoplankton ditera dalam jumlah ind. per I. Penentuan kelimpahan individu dilakukan dengan menggunakan metode Lackey Drop Microtransect Counting (APHA, 1989) dengan persamaan sebagai berikut:

$$
\mathrm{N}=\mathrm{n} \times \underline{\mathrm{A}} \times \underline{\mathrm{C}} \times \underline{\mathrm{E}} \times
$$

di mana:

$$
\begin{aligned}
N= & \text { jumlah total plankton } \\
N= & \text { jumlah rataan total individu per lapang } \\
& \text { pandang } \\
A= & \text { luas gelap penutup }\left(\mathrm{mm}^{2}\right) \\
B= & \text { luas lapang pandang }\left(\mathrm{mm}^{2}\right) \\
C & =\text { volume air terkonsentrasi }(\mathrm{ml}) \\
D & =\text { volume air } 1 \text { tetes }(\mathrm{ml}) \text { di bawah gelas penutup } \\
E & =\text { volume air yang disaring }(\mathrm{I})
\end{aligned}
$$

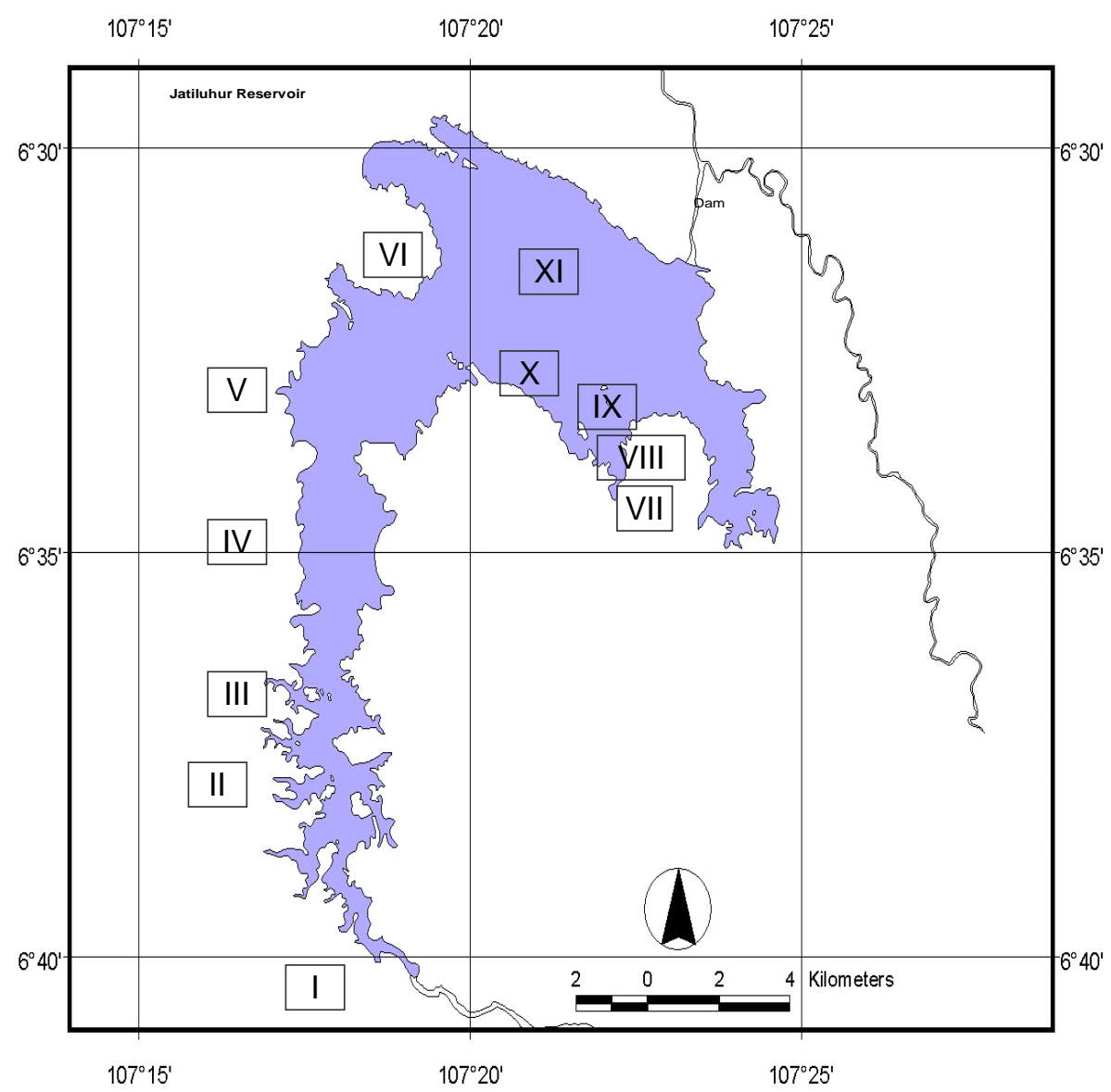

Gambar 1. Waduk Ir. H. Djuanda dan stasiun pengamatan.

Figure 1. Ir. H. Djuanda Reservoir and observation station.

Tabel2. Metode yang digunakan dalam pengamatan kualitas air di Waduk Ir. H. Djuanda Table 2. The method used in observation of water quality in Ir. H. Djuanda Reservoir

\begin{tabular}{clcl}
\hline No. & \multicolumn{1}{c}{$\begin{array}{c}\text { Parameter/ } \\
\text { Parameter }\end{array}$} & $\begin{array}{c}\text { Satuan } \\
\text { (unit) }\end{array}$ & \multicolumn{1}{c}{$\begin{array}{c}\text { Metode dan alat/ } \\
\text { Method and tool }\end{array}$} \\
\hline 1. & Kecerahan & $\mathrm{cm}$ & In situ, Secchi disk \\
2. & $\mathrm{pH}$ & unit & In situ, pH indicator \\
3. & $\mathrm{O}_{2}$ & $\mathrm{mg} / \mathrm{l}$ & In situ, Oxygen meter \\
4. & $\mathrm{CO}_{2}$ & $\mathrm{mg} / \mathrm{l}$ & In situ,Titrasi, $\mathrm{Na}_{2} \mathrm{CO}_{3}$ \\
5. & $\mathrm{N}_{2} \mathrm{NO}_{3}$ & $\mathrm{mg} / \mathrm{l}$ & Laboratorium, Spektrofotometer, Brusine Sulfat \\
6. & $\mathrm{N}_{-}-\mathrm{NH}_{4}$ & $\mathrm{mg} / \mathrm{l}$ & Laboratorium, Spektrofotometer, Nessler \\
7. & $\mathrm{P}_{-} \mathrm{PO}_{4}$ & $\mathrm{mg} / \mathrm{l}$ & Laboratorium, Spektrofotometer, Stanno chlorida \\
\hline
\end{tabular}




\section{HASIL DAN BAHASAN}

Waduk Ir. H. Djuanda mempunyai kecerahan berkisar 10 sampai dengan $180 \mathrm{~cm}$ (Gambar 2). Kecerahan terendah di stasiun Cilalawi dan Parung Kalong pada bulan April dan Desember. Jika dilihat dari warna air yang coklat kemungkinan kecerahan yang rendah ini diakibatkan oleh tinggi bahan organik dan banyak partikel-partikel tanah. Bahan organik ini kemungkinan berasal dari Waduk Cirata dan limpasan tanah pucuk (top soi), karena catchment area di sekitar inlet Cilalawi merupakan daerah persawahan. Kecerahan tersebut lebih rendah dibandingkan kecerahan waduk yang sama pada tahun 1983 (Krismono \& Hardjamulia, 1986).

Derajat keasaman $(\mathrm{pH})$ di Waduk Ir. H. Djuanda berkisar antara 7,0 sampai dengan 9,0 unit, tetapi pada umumnya mempunyai $\mathrm{pH}$ netral $\mathrm{pH}$ rata-rata $7,3)$. Derajat keasaman $(\mathrm{pH})$ yang demikian ini mendukung kegiatan perikanan seperti pendapat
Boyd (1982) yaitu berkisar antara 6 sampai dengan 9. Derajat keasaman menggambarkan kemampuan suatu badan air untuk menetralkan ion hidrogen yang masuk ke badan air (Effendi, 2003). Stasiun pengamatan yang memiliki $\mathrm{pH}$ yang tinggi pada umumnya memiliki alkalinitas tinggi dan kadar karbondioksida yang rendah. Sebagian besar biota akuatik sensitif terhadap perubahan $\mathrm{pH}$ dan menyukai nilai $\mathrm{pH}$ berkisar 7 sampai dengan 8,5. Derajat keasaman juga sangat mempengaruhi toksisitas suatu senyawa kimia (Effendi, 2003). Hasil pengamatan $\mathrm{pH}$ tersebut relatif sama dengan $\mathrm{pH}$ perairan pada tahun 1983 (Krismono \& Hardjamulia, 1986).

Oksigen terlarut merupakan parameter penting yang menentukan kualitas air. Konsentrasi oksigen terlarut di permukaan berkisar 3,5 sampai dengan $5,6 \mathrm{mg}$ per I dan di dasar perairan berkisar 2,5 sampai dengan 4,4 mg per I (Gambar 3).

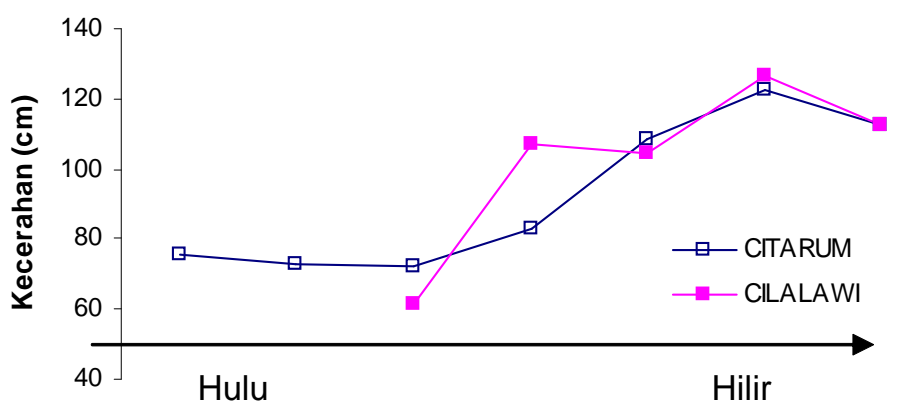

Gambar 2. Rata-rata kecerahan menurut stasiun pengamatan alur Sungai Citarum dan Sungai Cilalawi. Figure 2. Average transparancy according to observation station according to Citarum and Cilalawi groove

Gambar 3 menunjukkan bahwa stasiun inlet Sungai Citarum mempunyai rata-rata oksigen terlarut terendah di permukaan dan kedalaman $2 \mathrm{~m}$. Hal tersebut, diduga disebabkan oleh masukan dari Waduk Cirata yang membawa bahan organik yang jauh lebih besar dibandingkan Sungai Cilalawi, sehingga di stasiun inlet Citarum terjadi penguraian bahan organik oleh mikroorganisme. Dalam proses penguraian tersebut memerlukan oksigen sehingga menurunkan kosentrasi oksigen terlarut di daerah tersebut. Masukan bahan organik yang berasal dari kegiatan budi daya ikan di Waduk Cirata jauh lebih besar dibandingkan yang berasal dari Waduk Ir. $\mathrm{H}$. Djuanda. Kondisi tersebut dapat dilihat dari jumlah unit karamba jaring apung yang ditetapkan dan realisasi. Jumlah karamba jaring apung di Waduk Ir. H. Djuanda pada tahun 2005 yaitu 4.577 unit dan tahun 2006 yaitu 15.000 unit karamba jaring apung, padahal jumlah yang diizinkan berdasarkan pada
S.K. Bupati Purwakarta No.06/2000 hanya 2.100 unt. Di Waduk Cirata $(A=6.200$ ha dan $Z=34,9 \mathrm{~m})$ jumlah karamba jaring apung yang beroperasi mencapai 39.690 unit (tahun 2005), meskipun jumlah yang diizinkan hanya 12.000 unit (berdasarkan pada S.K. Gubernur Jawa Barat No.41/2002).

Data konsentrasi oksigen terlarut di stasiun karamba jaring apung, daerah air minum dan perusahaan daerah air minum menunjukkan ada stratifikasi terhadap distribusi vertikal oksigen terlarut, di mana lapisan hipolimnion ditemukan mulai pada kedalaman $8 \mathrm{~m}$ (Gambar 4), sedangkan pada lapisan metalimnion dan epilimnion konsentrasi oksigen terlarut berkisar antara 2,0 sampai dengan $6,0 \mathrm{mg}$ per I. Lapisan epilimnion di ke-2 stasiun sangat tipis (kurang dari $5 \mathrm{~m}$ ). Perbandingan dengan distribusi vertikal oksigen terlarut antara tahun 2004 sampai dengan 2006, menunjukkan bahwa konsentrasi 
oksigen pada tahun 2006 lebih rendah (Gambar 5). Hal tersebut, berarti kondisi kualitas air Waduk Ir. $\mathrm{H}$. Djuanda cenderung menurun yang berbanding terbalik dengan jumlah karamba jaring apung yang beroperasi. Hal tersebut, menunjukkan pengembangan karamba jaring apung telah melampaui daya dukung perairan dan sudah menunjukkan kecenderungan mencemari lingkungan. Upaya untuk memperbaiki kualitas perairan tersebut tidak cukup dengan hanya mengurangi jumlah unit karamba jaring apung yang beroperasi di Waduk Ir. H. Djuanda, tetapi ada pengurangan jumlah unit karamba jaring apung di Waduk Cirata.

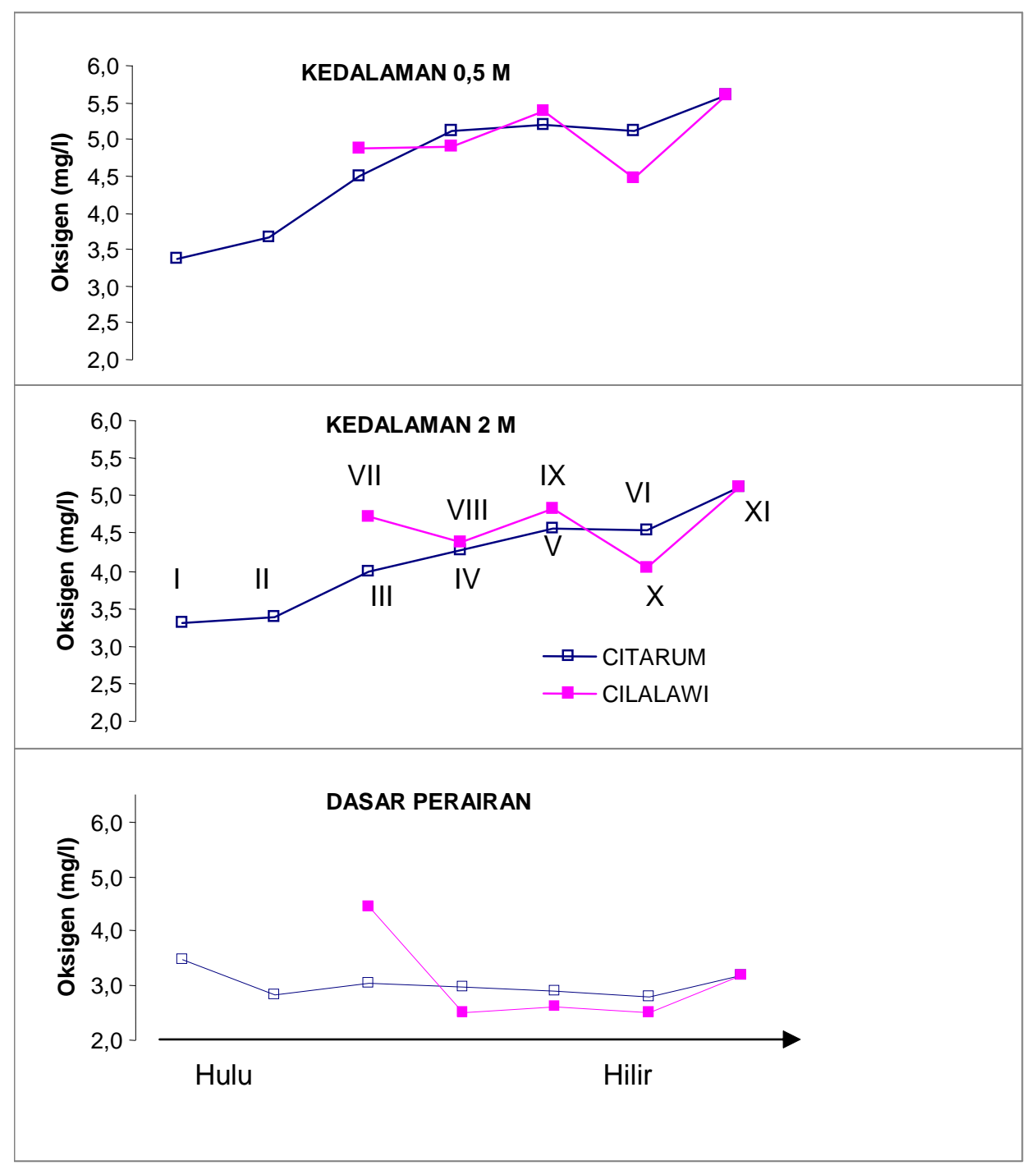

Gambar 3. Rata-rata oksigen terlarut pada kedalaman permukaan $(0,5 \mathrm{~m}), 2 \mathrm{~m}$ dan dasar perairan menurut stasiun pengamatan alur Sungai Citarum dan Sungai Cilalawi.

Figure 3. Average of dissolved oxygen ( $\mathrm{mg} / \mathrm{l})$ in surface $(0.5 \mathrm{~m}), 2 \mathrm{~m}$ and bottom waters by observation station groove of Citarum and Cilalawi River.

Konsentrasi karbondioksida di permukaan berkisar antara tidak terdeteksi sampai dengan 17,92 mg per I dan di dasar perairan berkisar tidak terdeteksi sampai dengan 29,12 mg per I di Stasiun Sodong (II) (Gambar 5). Konsentrasi karbondioksida bebas di Waduk Ir. $\mathrm{H}$. Djuanda yang tinggi pada umumnya terdapat di dasar perairan.
Berdasarkan pada Gambar 6 menunjukkan bahwa konsentrasi $\mathrm{CO}_{2}$ bebas di daerah inlet Sungai Citarum selalu menunjukkan nilai yang tertinggi. Distribusi horisontal $\mathrm{CO}_{2}$ bebas tersebut berbading terbalik dengan distribusi horisontal oksigen terlarut. Hal tersebut, dapat diartikan bahwa sumber bahan organik tertinggi di Waduk Ir. H. Djuanda berasal dari Waduk Cirata. Kondisi ini kurang menguntungkan bagi 
pembudidaya ikan, karena perbaikan kualitas air di perairan waduk ini tidak cukup dengan mengurangi jumlah unit karamba jaring apung di Waduk Ir. $\mathrm{H}$. Djuanda, tetapi terintegrasi secara nyata dengan pengurangan karamba jaring apung di Waduk Cirata.

Konsentrasi $\mathrm{N}-\mathrm{NO}_{2}$ di permukaan air Waduk Ir. $\mathrm{H}$. Djuanda berkisar antara tidak terdeteksi sampai dengan 1,08 mg per I dan di dasar perairan tt sampai dengan 0,447 mg per I. Konsentrasi nitrit tertinggi ada di daerah inlet Citarum, dan seperti hal $\mathrm{O}_{2}, \mathrm{CO}_{2}$, dan kecerahan diduga menunjukkan masalah pokok yang sama yaitu bahan organik dari Waduk Cirata yang masuk ke Waduk Ir. H. Djuanda lebih banyak dibandingkan dari Sungai Cilalawi maupun dari karamba jaring apung di Waduk Ir. H. Djuanda. Hasil pengamatan tersebut secara umum lebih tinggi dibandingkan pengamatan kualitas air di Waduk Ir. H. Djuanda pada tahun 1983 (Krismono \& Hardjamulia, 1986); 1990 (Krismono \& Purnomo, 1991). Perbedaan tersebut diduga disebabkan oleh masukkan bahan organik pada tahun 2004 sampai dengan 2006 lebih tinggi dibandingkan tahun 1983 maupun 1990. Hal tersebut, berarti perairan Waduk Ir. H. Djuanda tahun 2004 sampai dengan 2006 lebih tercemar dibandingkan pada tahun 1983 maupun 1990.

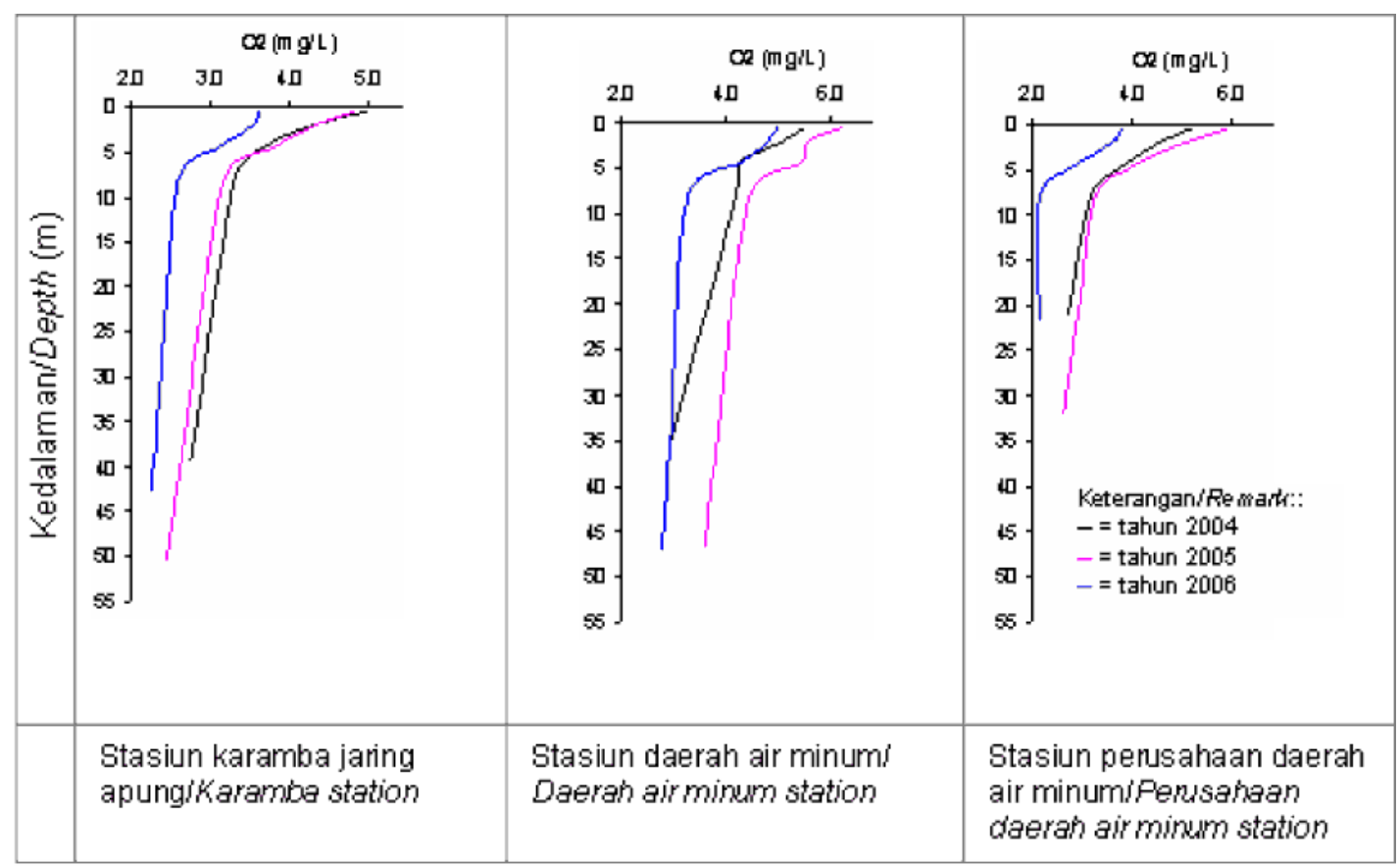

Gambar 4. Hubungan antara konsentrasi oksigen terlarut (mg per I) dengan kedalaman ( $m$ ) di stasiun pengamatan karamba jaring apung, daerah air minum, dan perusahaan daerah air minum pada tahun 2004 (-), 2005 (-), dan 2006 (-).

Figure 4. Depth profile of dissolved oxigen ( $m g$ per $\mathrm{l}$ ) in karamba jaring apung, daerah air minum, and perusahaan daerah air minum observation stations in 2004 (-), 2005 (-), and 2006 (-).

Konsentrasi $\mathrm{N}-\mathrm{NO}_{3}$ berkisar antara tt sampai dengan 5,442 $\mathrm{mg}$ per I dengan pola distribusi horisontal relatif sama antara kedalaman $0,5 \mathrm{~m}, 2 \mathrm{~m}$ dan dasar perairan (Gambar 7). Pada alur Sungai Citarum menunjukkan bahwa peningkatan kandungan $\mathrm{N}-\mathrm{NO}_{3}$ dari hulu stasiun I (Parung Kalong) sampai dengan stasiun IV (Jamaras), setelah itu kandungan $\mathrm{N}-\mathrm{NO}_{3}$ menurun sampai dengan mencapai daerah air minum. Hal ini, kemungkinan diakibatkan oleh penguraian bahan organik yang berasal dari kegiatan budi daya ikan dalam karamba jaring apung dan nitrat dari hasil penguraian bahan organik yang berasal dari Waduk Cirata. Gambar 7 menunjukkan bahwa bahan organik yang berasal dari Waduk Cirata terurai menjadi nitrat melalui proses yang panjang (bahan organik $\rightarrow$ amonium $\rightarrow$ nitrit $\rightarrow$ nitrat) dan memerlukan waktu yang cukup lama. Selama material organik tersebut terbawa arus, dan proses tersebut diperkirakan sudah selesai setelah mencapai stasiun IV (Jamaras) dan V (Kerenceng).

Salah satu sumber nitrat kemungkinan berasal dari dekomposisi bahan organik dari pengendapan sisa pakan dan feses ikan, yang berasal dari sistem karamba jaring apung di Waduk Ir. H. Djuanda maupun Waduk Cirata. Menurut Krismono \& Krismono (2003) konsentrasi $\mathrm{N}-\mathrm{NO}_{3}$ yang tinggi dapat menstimulir 


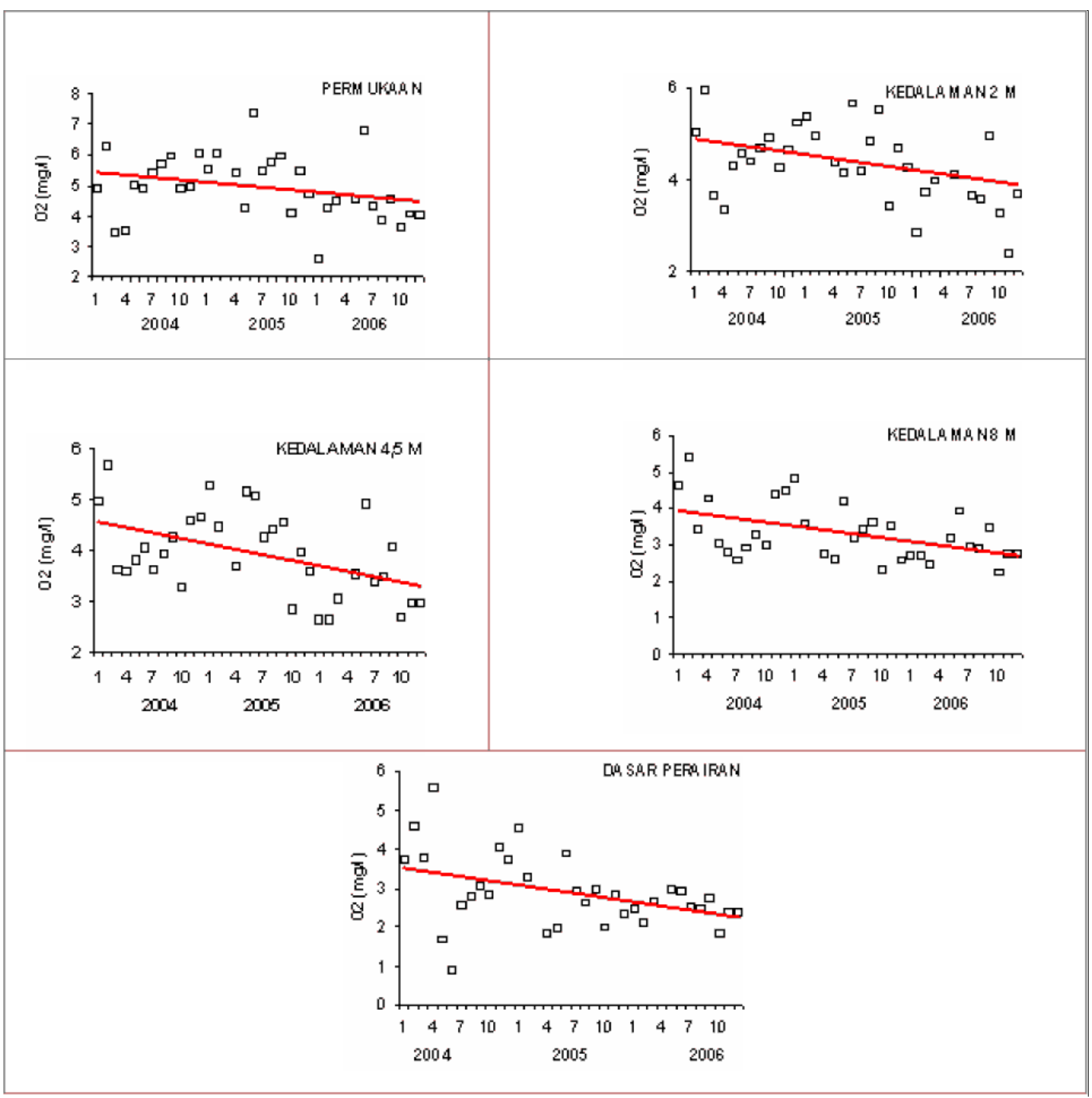

Gambar 5. Rata-rata oksigen ( $\mathrm{mg}$ per I) terlarut pada kedalaman permukaan $(0,5 \mathrm{~m}), 2 ; 4,5$; dan $8 \mathrm{~m}$ dan dasar perairan menurut waktu pengamatan.

Figure 5. Average of dissolved oxygen ( $\mathrm{mg}$ per $\mathrm{l}$ ) in surface $(0,5 \mathrm{~m}), 2 ; 4,5$; and $8 \mathrm{~m}$ and bottom waters by obeservation times.

pertumbuhan alga (blooming alga) di Waduk Ir. $\mathrm{H}$. Djuanda, Jatiluhur, Jawa Barat.

Berdasarkan pada distribusi vertikal konsentrasi nitrat di stasiun karamba, daerah air minum, dan perusahaan daerah air minum pada tahun 2004 sampai dengan 2006 (Gambar 8), menunjukkan bahwa ada peningkatan konsentrasi nitrat secara nyata dari tahun 2004 dan 2005 ke tahun 2006. Kondisi tersebut berarti ada peningkatan kesuburan yang nyata di Waduk Ir. H. Djuanda, di mana secara umum akan menguntungkan perikanan tangkap dan merugikan perikanan budi daya. Menguntungkan perikanan tangkap karena dengan peningkatan kesuburan perairan akan meningkatkan daya dukung biomassa ikan liar, dan sebaliknya untuk kegiatan perikanan budi daya.

Fitoplankton dalam pertumbuhan memerlukan unsur-unsur $\mathrm{O}, \mathrm{H}, \mathrm{C}, \mathrm{Si}, \mathrm{N}, \mathrm{Ca}, \mathrm{K}, \mathrm{P}, \mathrm{Mg}, \mathrm{S}, \mathrm{Cl}, \mathrm{Na}$, dan Fe (Kimmel, 1990). Unsur $\mathrm{N}$ dalam bentuk ammonia terionisasi (ammonium) dan nitrat sangat 

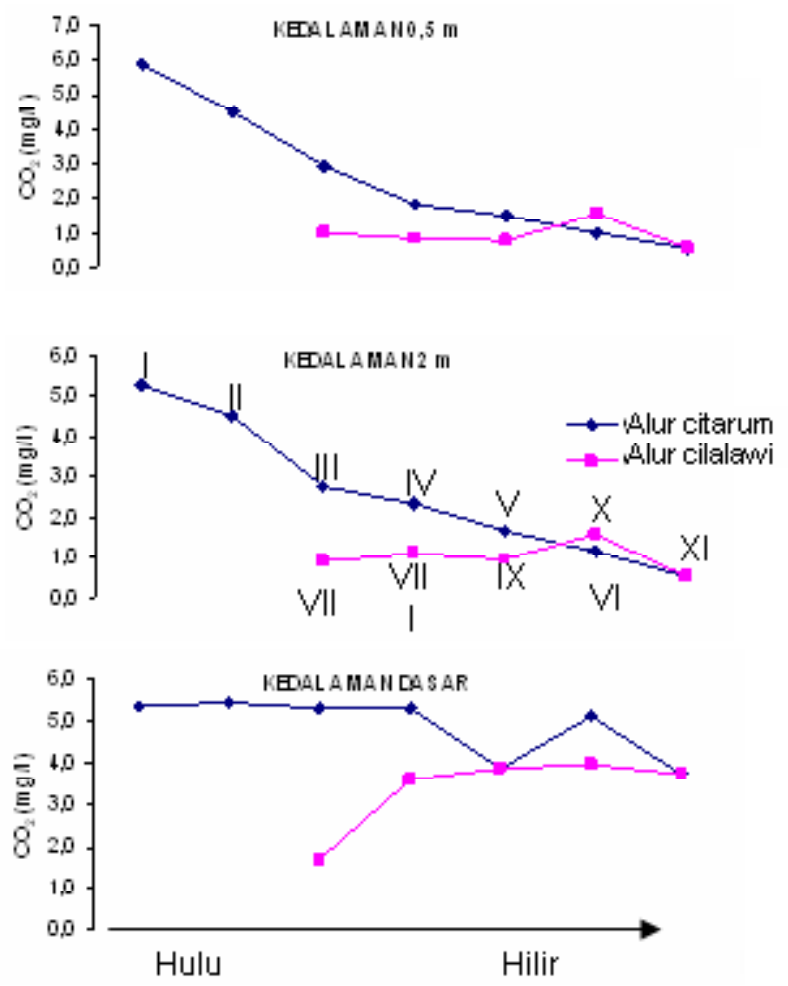

Gambar 6. Rata-rata Karbon aıoksıa (mg per I) pepas paaa keaaıaman permukaan (0,5 m), $2 \mathrm{~m}$, dan dasar perairan menurut stasiun pengamatan alur Sungai Citarum dan Cilalawi.

Figure 6. Average of carbon dioxide ( $\mathrm{mg}$ per $\mathrm{l})$ in surface $(0,5 \mathrm{~m}), 2 \mathrm{~m}$, and bottom waters by obeservation station groove of Citarum and Cilalawi River.
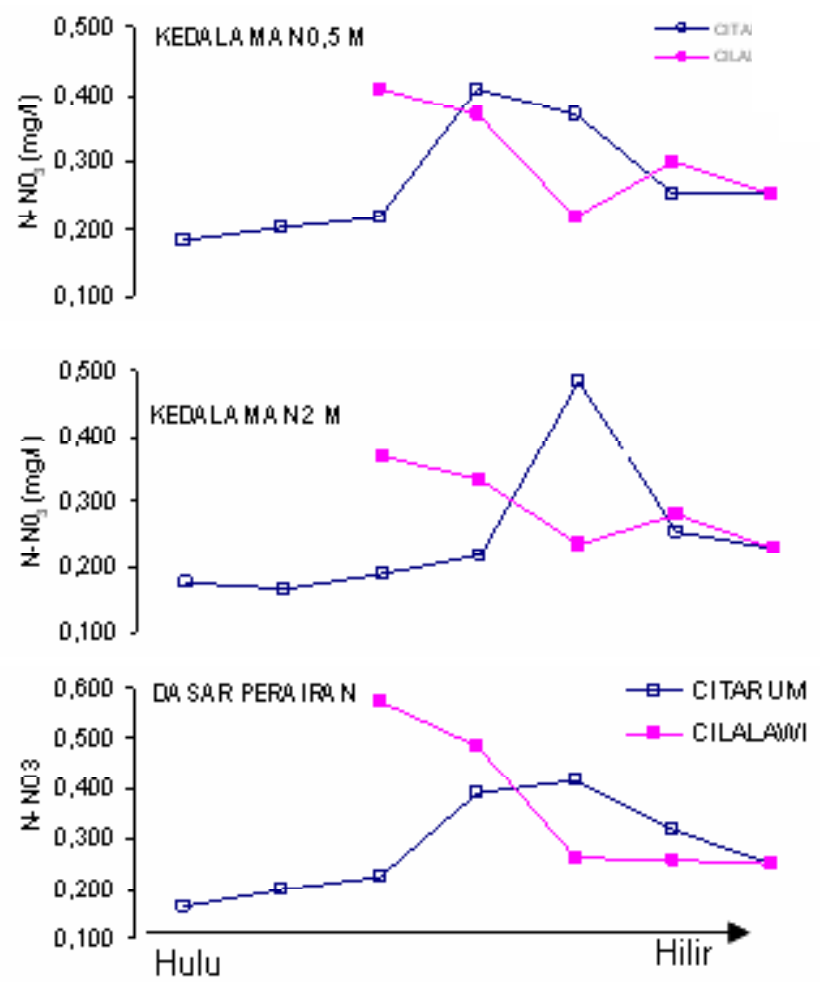

Gambar 7. Rata-rata nitrat ( $\mathrm{mg}$ per I) pada kedalaman permukaan $(0,5 \mathrm{~m}), 2 \mathrm{~m}$ dan dasar perairan menurut stasiun pengamatan alur Sungai Citarum dan Cilalawi.

Figure 7. Average of $\mathrm{N}-\mathrm{NO}_{3}$ ( $\mathrm{mg}$ per $\left.\mathrm{l}\right)$ in surface $(0,5 \mathrm{~m}), 2 \mathrm{~m}$ and bottom waters by observation station groove of Citarum and Cilalawi River. 
diperlukan oleh produksi primer untuk proses fotosintesis (Jørgensen, 1986), dipihak lain amonia terionisasi di perairan membentuk keseimbangan dengan amonia bebas dan keseimbangan tersebut sangat dipengaruhi oleh suhu dan $\mathrm{pH}$ (Boyd, 1990).

Amonia terdiri atas 2 macam yaitu amonia terionisasi $\left(\mathrm{N}-\mathrm{NH}_{4}\right)$ dan amonia bebas $\left(\mathrm{N}-\mathrm{NH}_{3}\right)$. Amonia terionisasi atau ammonium merupakan salah satu bentuk $\mathrm{N}$ yang langsung dapat dimanfaatkan oleh tumbuhan air dan fitoplankton, sedangkan amonia bebas atau amoniak merupakan bentuk $\mathrm{N}$ yang bersifat racun pada ikan dan tingkat keracunan sangat dipengaruhi oleh $\mathrm{pH}$ perairan dan stadia hidup ikan (Boyd, 1990). Untuk benih ikan mas konsentrasi N$\mathrm{NH}_{3}$ tidak lebih dari 2,0 mg per I (Hasan \& Macintosh dalam Boyd, 1990), telur lebih toleran terhadap N$\mathrm{NH}_{3}$ sampai dengan $11,83 \mathrm{mg}$ per I untuk daya tetas $50 \%$, tetapi untuk larva hanya toleran sampai dengan 0,34 mg per I dan untuk juvenil 2,40 mg per I (Boyd, 1990).

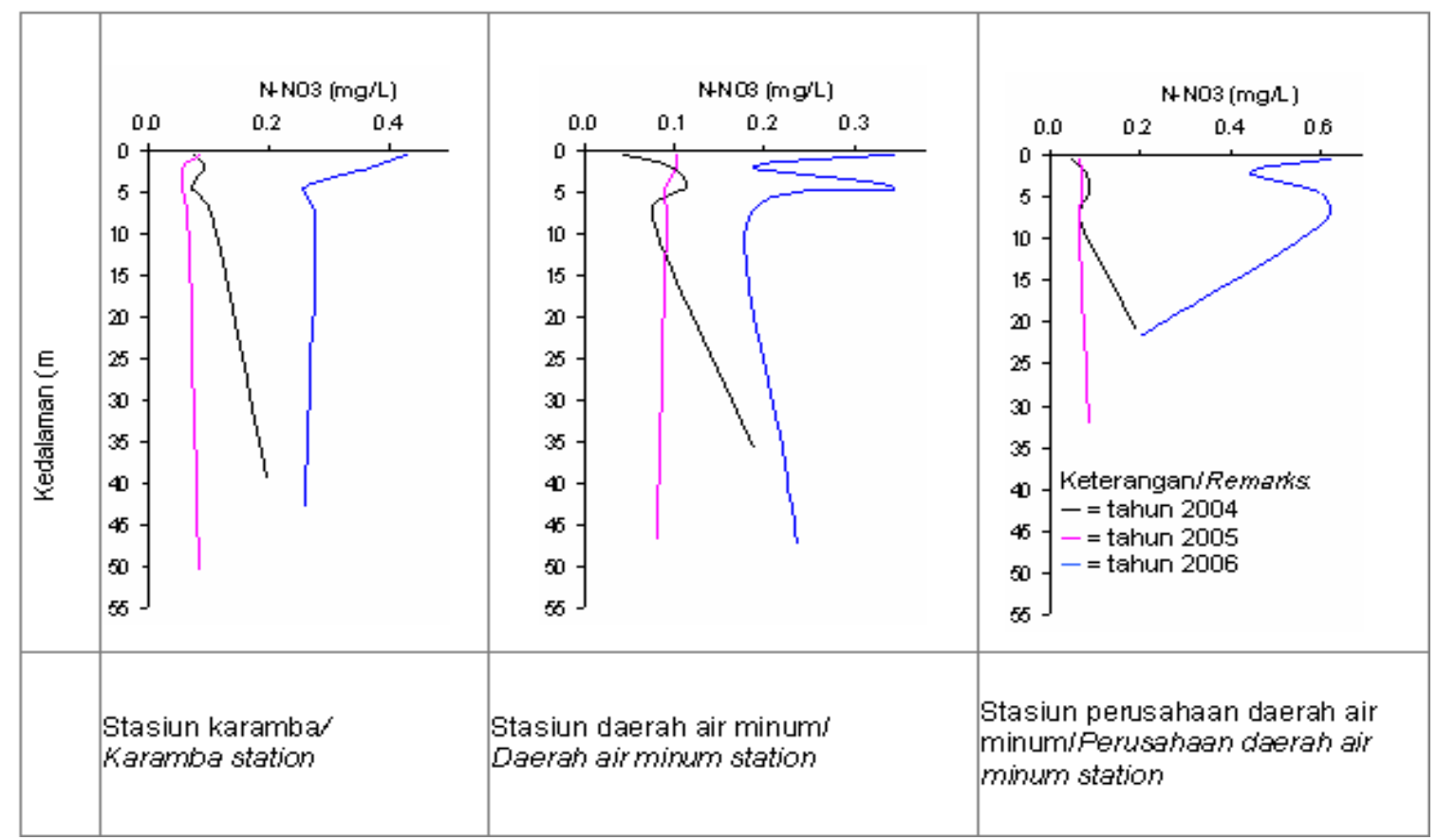

Gambar 8. Hubungan antara konsentrasi $\mathrm{N}-\mathrm{NO}_{3}(\mathrm{mg}$ per $\mathrm{l})$ dengan kedalaman $(\mathrm{m})$ di stasiun pengamatan karamba, daerah air minum, dan perusahaan daerah air minum pada tahun 2004 (-), 2005 (-), dan $2006(-)$.

Figure 8. Interaction between $\mathrm{N}-\mathrm{NO}_{3}(\mathrm{mg}$ per I) with depth $(\mathrm{m})$ in karamba, daerah air minum, and perusahaan daerah air minum observation stations in 2004 (-), 2005 (-), and 2006 (-).

Konsentrasi $\mathrm{N}-\mathrm{NH}_{4}$ berkisar antara tt sampai dengan 3,885 mg per I. Konsentrasi tertinggi di stasiun Parung Kalong (daerah hulu alur Sungai Citarum) (Gambar 9). Gambar tersebut menunjukkan pola yang sama dengan $\mathrm{N}-\mathrm{NO}_{3}$ dan $\mathrm{N}-\mathrm{NO}_{2}$, Hal tersebut membuktikan bahwa sumber $\mathrm{N}-\mathrm{NH}_{4}, \mathrm{~N}-\mathrm{NO}_{3}$, dan $\mathrm{N}$ $\mathrm{NO}_{2}$ di Waduk Ir. H. Djuanda berasal dari masukkan bahan organik dari Waduk Cirata dan diuraikan di daerah inlet Citarum. Gambar 9 menunjukkan bahwa masukkan utama $\mathrm{N}-\mathrm{NH}_{4}$ di Waduk Ir. H. Djuanda berasal dari Waduk Cirata. Proses penguraian bahan organik menjadi $\mathrm{N}-\mathrm{NH}_{4}$ memerlukan waktu yang lebih singkat dibandingkan pembentukan $\mathrm{N}-\mathrm{NO}_{2}$ dan $\mathrm{N}$ $\mathrm{NO}_{3}$, sehingga konsentrasi $\mathrm{N}-\mathrm{NH}_{4}$ tinggi di stasiun I (Parung Kalong), II (Sodong), dan III (Bojong). Konsentrasi $\mathrm{N}-\mathrm{NH}_{4}$ yang tinggi merupakan salah satu indikator bahwa kesuburan perairan tinggi, karena ada senyawa ini mampu mendorong pertumbuhan algae, tetapi konsentrasi $\mathrm{N}-\mathrm{NH}_{4}$ di karamba jaring apung diperhatikan, karena dalam keadaan anaerob $\mathrm{N}-\mathrm{NH}_{4}$ berubah menjadi $\mathrm{N}-\mathrm{NH}_{3}$ yang bersifat racun bagi ikan.

Fosfor merupakan nutrien kunci yang mempengaruhi tumbuhan air. Ortopospat $\left(\mathrm{P}-\mathrm{PO}_{4}\right)$ merupakan bentuk $P$ yang dapat dimanfaatkan oleh tumbuhan dan fitoplankton. Konsentrasi $\mathrm{P}_{-} \mathrm{PO}_{4}$ yang tinggi dapat menstimulir pertumbuhan alga (blooming algae). Konsentrasi rata-rata $\mathrm{P}-\mathrm{PO}_{4}$ per bulan untuk tahun 2004 sampai dengan 2006 berkisar 0,045 sampai dengan 1,044 mg per I, di mana pada awal dan akhir tahun konsentrasi $\mathrm{P}_{-} \mathrm{PO}_{4}$ tinggi (Gambar 10a). Hubungan rata-rata konsentrasi $\mathrm{P}-\mathrm{PO}_{4}$ di Waduk 
Ir. H. Djuanda terhadap waktu (bulan) mempunyai kecenderungan bersifat kuadratik. Hal tersebut, diduga berhubungan erat dengan tinggi muka air waduk, di samping itu berdasarkan pada distribusi horisontal kandungan $\mathrm{P}-\mathrm{PO}_{4}$ menunjukkan peningkatan yang sangat nyata di stasiun daerah air minum (Gambar 10b). Dengan demikian, diduga sumber utama $\mathrm{P}-\mathrm{PO}_{4}$ berasal dari dalam badan air (Waduk Ir. H. Djuanda). Sumber $P$ kemungkinan berasal dari dekomposisi bahan organik yang berasal dari sisa pakan ikan yang terakumulasi di dasar perairan.

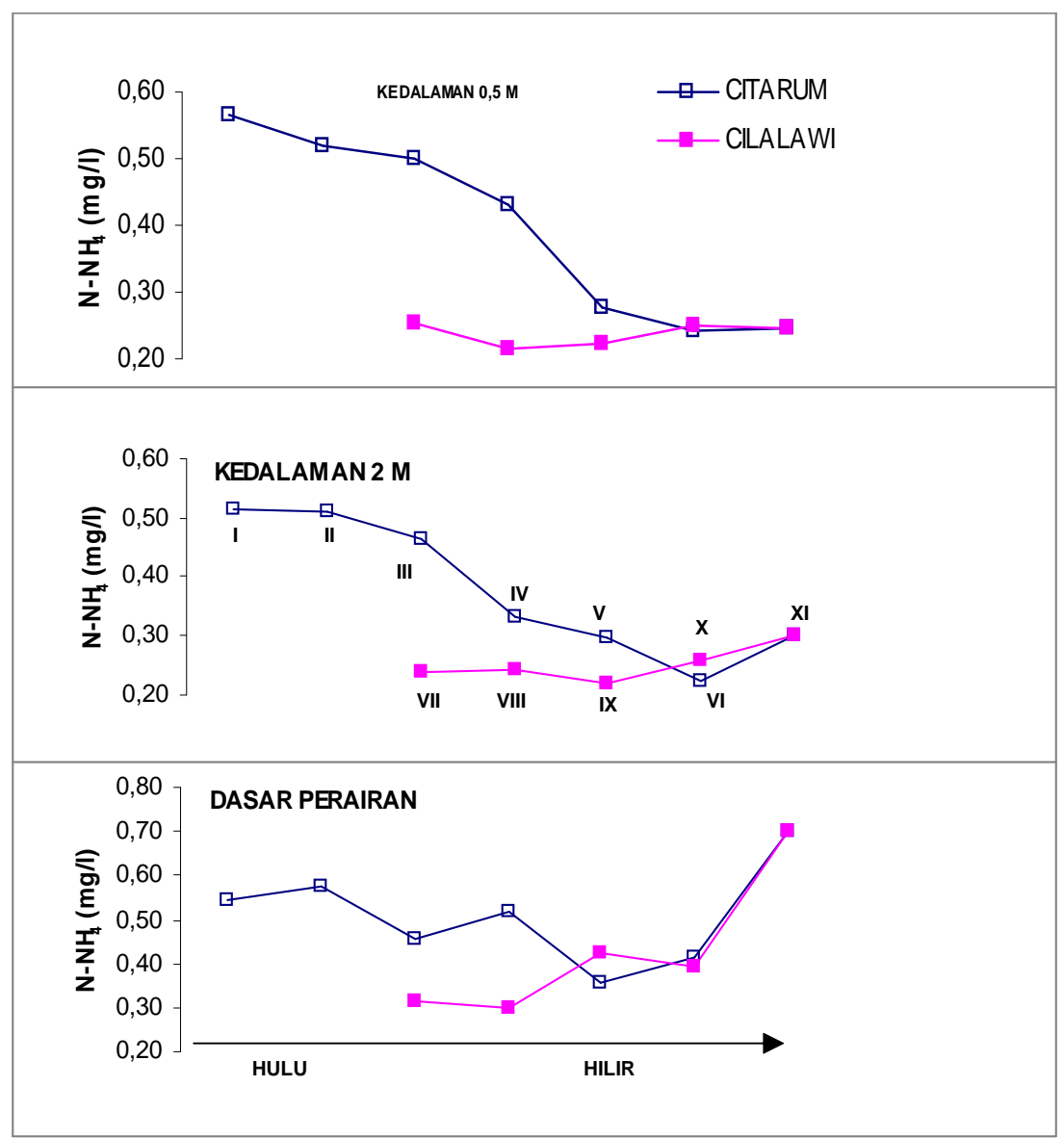

Gambar 9. Rata-rata $\mathrm{N}_{-} \mathrm{NH}_{4}$ (mg per I) pada kedalaman permukaan $(0,5 \mathrm{~m}), 2, \mathrm{~m}$ dan dasar perairan menurut stasiun pengamatan alur Sungai Citarum dan Cilalawi.

Figure 9. Average of $\mathrm{N}-\mathrm{NH}_{4}(\mathrm{mg}$ per I) in surface $(0,5 \mathrm{~m}), 2 \mathrm{~m}$, and bottom waters by obeservation station groove of Citarum and Cilalawi River.

Ditinjau dari konsentrasi rata-rata $\mathrm{P}-\mathrm{PO}_{4}$ di stasiun pengamatan karamba, daerah air minum, dan perusahaan daerah air minum terlihat ada kenaikan yang nyata setiap tahun pengamatan (Gambar 11). Berdasarkan pada klasifikasi tingkat trofik Carlson (Walker, 1990), fakta ini menunjukkan ada peningkatan tingkat eutrofikasi dari eutrofik (2004) menjadi hipereutrofik (tahun 2005 dan 2006). Hal tersebut, berarti peningkatan unit karamba jaring apung yang beroperasi di Waduk Ir. H. Djuanda telah melampaui daya dukung perairan tersebut dan cenderung mencemari perairan.

Kelimpahan plankton di Waduk Ir. H. Djuanda berkisar antara 23.686 sampai dengan 615.734 ind. per I dengan rata-rata 207.141 ind. per I (Gambar 12).
Gambar tersebut menunjukkan bahwa kecenderungan kelimpahan tertinggi pada bulan Pebuari dan menurun terus sampai dengan bulan Agustus sampai dengan September (pertengahan musim kemarau). Setelah itu, kelimpahan plankton perlahan-lahan meningkat sampai dengan bulan Desember dan antara bulan Desember sampai dengan Januari meningkat secara lebih cepat. Kecepatan peningkatan kelimpahan plankton pada bulan September sampai dengan Desember yang lebih rendah dibandingkan bulan Desember sampai dengan Januari disebabkan pada periode bulan September sampai dengan Desember sumber nutrien utama berasal dari Waduk Ir. $\mathrm{H}$. Djuanda. Pada bulan Desember sampai dengan Januari waduk ini mendapat tambahan nutrien yang tinggi dari waduk di atas (Waduk Cirata). 


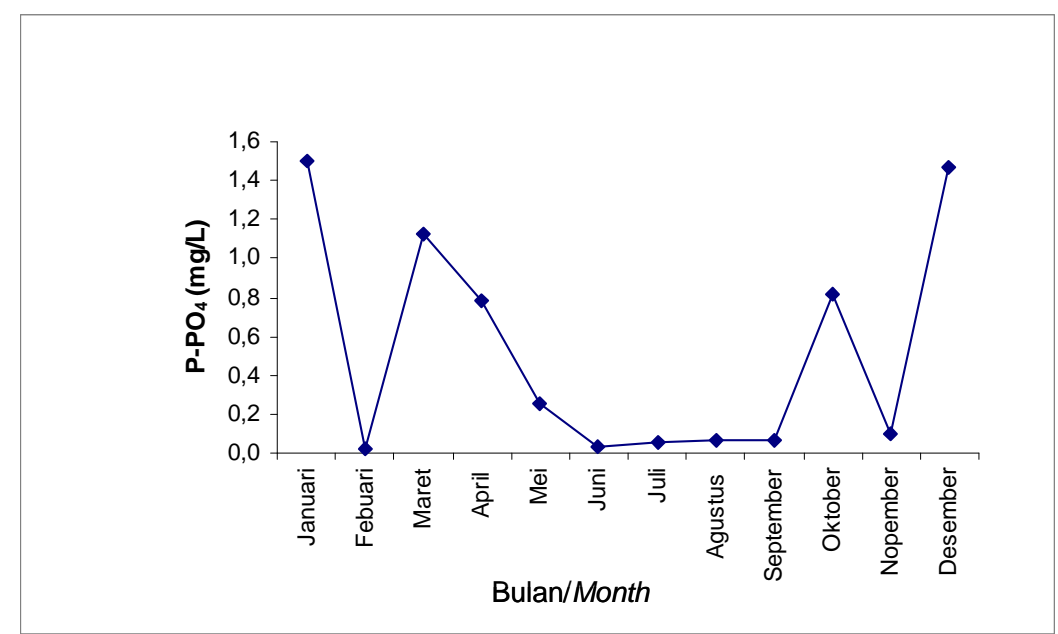

Gambar 10a. Hubungan antara rata-rata konsentrasi $\mathrm{P}_{-}-\mathrm{PO}_{4}$ (mg per I) di Waduk Ir. H. Djuanda terhadap waktu pengamatan (bulan).

Figure 10a. Relationship between average of concentrasion $\mathrm{P}_{-} \mathrm{PO}_{4}(\mathrm{mg}$ per I) in Ir. H. Djuanda Reservoir and observation time (month).

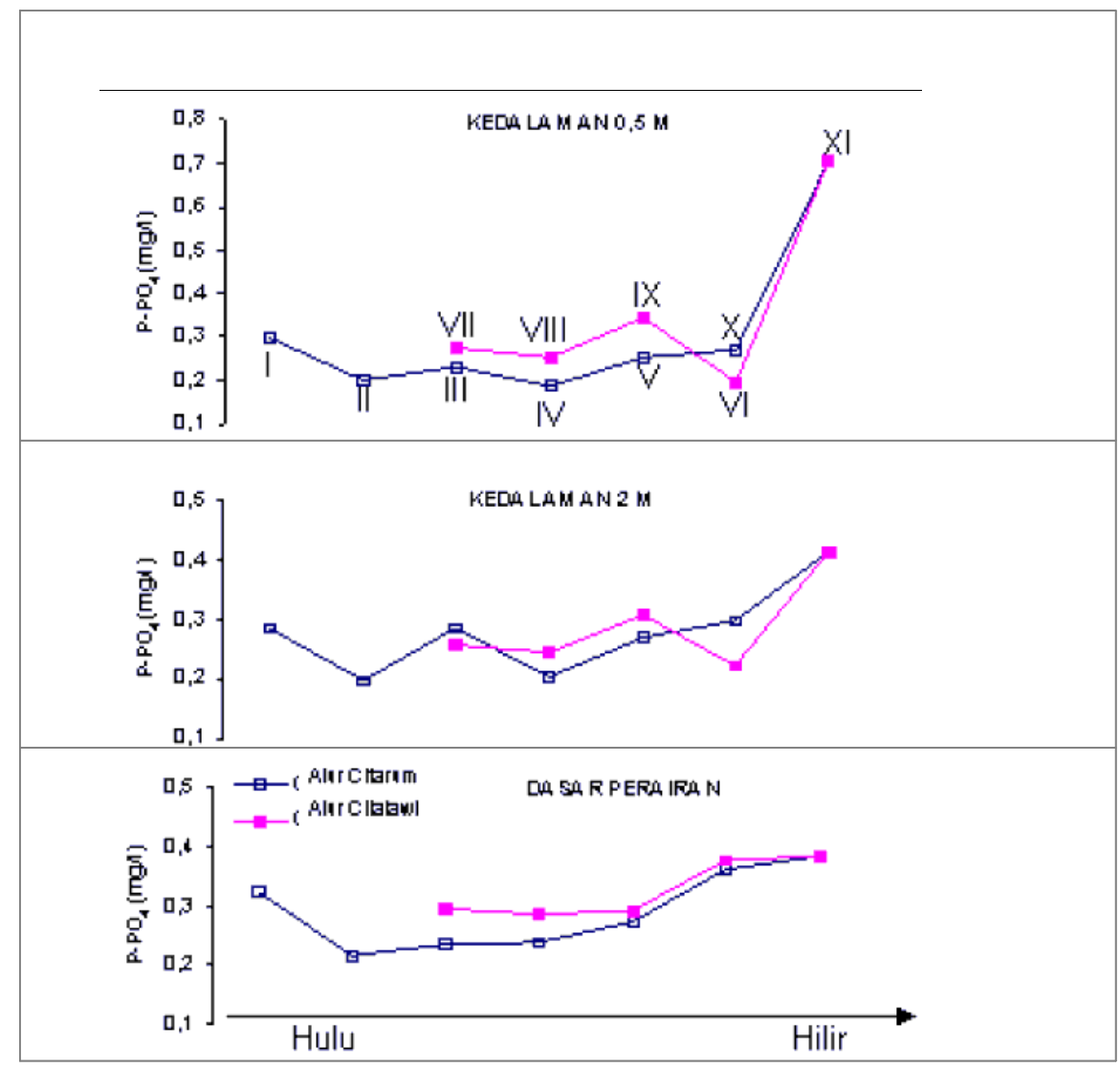

Gambar 10b. Rata-rata $\mathrm{P}_{-} \mathrm{PO}_{4}$ (mg per I) pada kedalaman permukaan $(0,5 \mathrm{~m}), 2 \mathrm{~m}$ dan dasar perairan menurut stasiun pengamatan alur Sungai Citarum dan Cilalawi.

Figure 10b. Average of $\mathrm{P}_{-} \mathrm{PO}_{4}(\mathrm{mg}$ per $\mathrm{l})$ in surface $(0,5 \mathrm{~m}), 2 \mathrm{~m}$ and bottom waters by obeservation station groove of Citarum and Cilalawi River. 


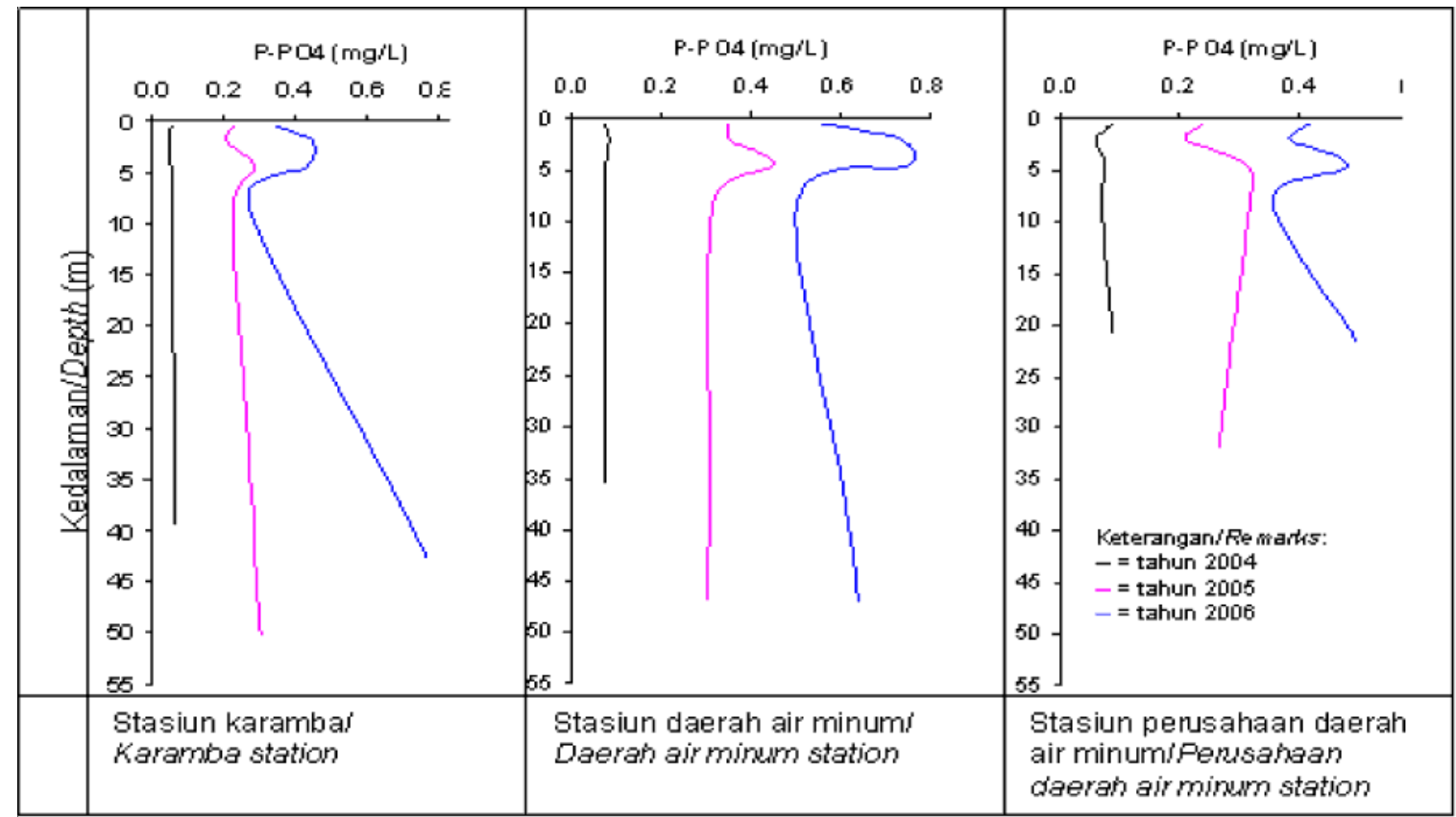

Gambar 11. Hubungan antara konsentrasi $\mathrm{P}-\mathrm{PO}_{4}(\mathrm{mg}$ per I) dengan kedalaman $(\mathrm{m})$ di stasiun pengamatan karamba, daerah air minum, dan perusahaan daerah air minum pada tahun 2004 (-), 2005 (一), dan $2006(-)$.

Figure 11. Interaction between $\mathrm{P}_{-} \mathrm{PO}_{4}(\mathrm{mg}$ per $\mathrm{I})$ with depth $(\mathrm{m})$ in karamba, daerah air minum, and perusahaan daerah air minum observation stations in 2004 (-), 2005 (-), and 2006 (-).

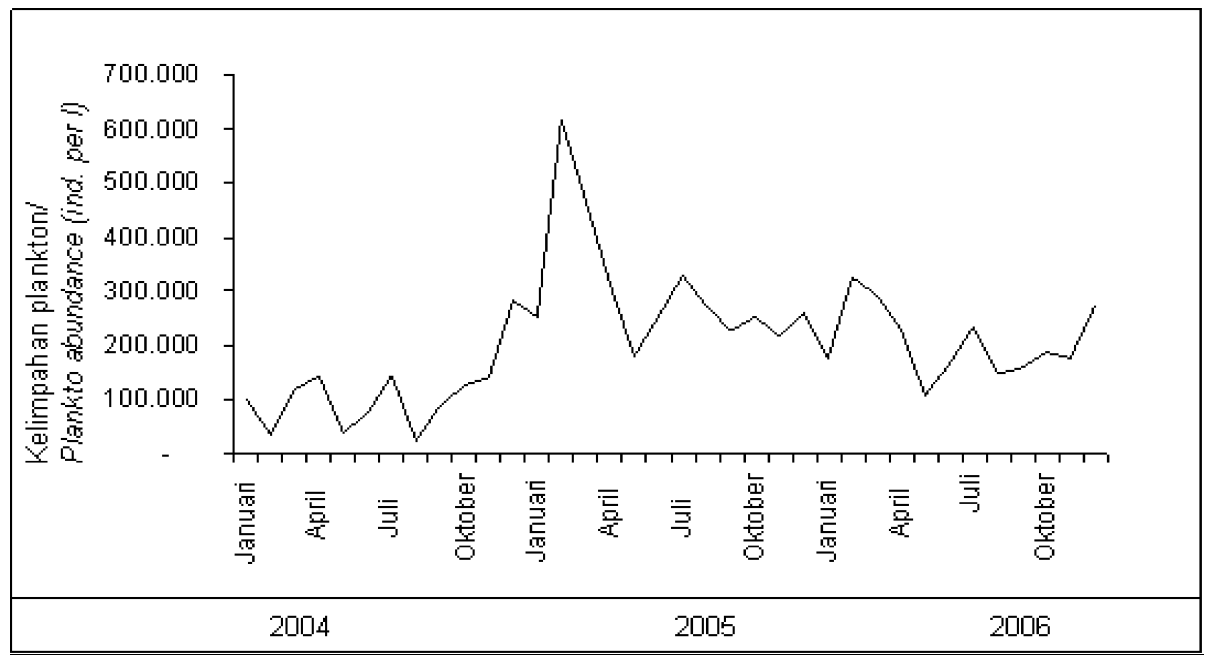

Gambar 12. Kelimpahan plankton di Waduk Ir. H. Djuanda menurut waktu pengamatan (bulan dan tahun). Figure 12. Pankton abundance according to the observation time (months and years) in Ir. H. Djuanda Reservoir

Kandungan nutrien yang tinggi ( $\mathrm{N}$ dan $\mathrm{P}$ ) pada batas-batas tertentu akan merangsang pertumbuhan plankton dengan cepat, sehingga pada kondisi ini mendorong terjadi blooming algae, sedangkan peningkatan kandungan nutrien yang melebihi batas tersebut akan mencemari lingkungan. Blooming plankton tersebut cenderung berdampak negatif terhadap kegiatan budi daya ikan intensif dalam karamba jaring apung, yaitu pada kondisi ini mendorong terjadi defisit oksigen pada saat cuaca mendung sepanjang hari selama 3 hari atau lebih.

Upaya dalam mengatasi dampak negatif tersebut dapat dilakukan dengan 2 cara yang dilaksanakan di Waduk Ir. H. Djuanda maupun Waduk Cirata, yaitu pengurangan kegiatan budi daya ikan dalam karamba 
jaring apung dan penebaran ikan yang mampu memanfaatkan plankton secara intensif. Pengurangan kegiatan budi daya dapat dilakukan dengan beberapa cara, antara lain 1) perbaikan teknologi budi daya ikan dalam karamba jaring apung; 2) perbaikan pola tanam; dan 3) pengurangan biomassa ikan yang dipelihara melalui pengurangan jumlah unit karamba jaring apung yang beroperasi ataupun pengurangan padat tebar, sedangkan untuk penebaran ikan dapat dilakukan dengan mengkombinasikan antara jenis ikan pemakan plankton yang bersifat pelagis, misal bandeng (Chanos chanos) dan mola (Hypophthalmichthys molitrix), dan jenis ikan pemakan plankton yang bersifat litoral, seperti ikan nila (Oreochromis niloticus).

\section{KESIMPULAN}

Sumber utama degradasi kualitas air di Waduk Ir. H. Djuanda adalah bahan organik dari Waduk Cirata. Berdasarkan pada distribusi vertikal oksigen di perairan ini terjadi stratifikasi dengan kedalaman epilimnion sangat tipis. Tingkat kesuburan perairan menurut kandungan fosfat dan nitrogen, perairan Waduk Ir. H. Djuanda telah berubah dari eutrofik pada tahun 2004 menjadi hipereutrofik pada tahun 2005 dan 2006. Degradasi tersebut cenderung meningkat seiring dengan peningkatan jumlah unit karamba jaring apung yang dikembangkan di Waduk Cirata dan Waduk Ir. H. Djuanda. Hal tersebut, patut diduga bahwa pengembangan kegiatan budi daya dalam karamba jaring apung telah melampaui daya dukung dan cenderung telah mencemari perairan. Upaya mengatasi degradasi tersebut dengan 2 cara, yaitu 1) mengurangi usaha budi daya ikan dalam karamba jaring apung di Waduk Ir. H. Djuanda dan Cirata dan 2) menebarkan jenis ikan yang mampu memanfaatkan plankton secara efektif.

\section{PERSANTUNAN}

Kegiatan dari hasil riset monitoring sumber daya perikanan waduk Ir. H. Djuanda, T. A. 2006, di Loka Riset Pemacuan Stok Ikan, Jatiluhur-Purwakarta.

\section{DAFTAR PUSTAKA}

APHA. 1989. Standart method the examination and wastewater. Washington, D. C. Am. Public Health Ass. Am. Water Works Ass. 1.134 p.

Boyd, C. E. 1982. Water quality management for pond fish culture. Elsevier Science Publishers Company. New York. 318 p.
Boyd, E. C. 1990. Water quality in ponds for aquaculture. Birmingham Publishing Co. Birmingham. $442 \mathrm{p}$.

Effendi, H. 2003. Telaah kualitas air bagi pengelolaan sumber daya dan lingkungan perairan. Kanisius. Yogyakarta. $258 \mathrm{p}$.

Jørgensen, S. E. 1986. Fundamental of ecological modelling. Elsevier Science Publishers B. V. Amsterdam. 387 p.

Kimmell, B. 1990. Ecological concepts. In Olem, H. \& G. Flock (eds.) Lake and Reservoir Restoration Guidance Manual. 2nd edition. EPA440/4-90-006. Prep. By N. Am. Lake Manage. Soc. For U. S. Environ. Prot.Agency. Washington. D. C. 7-34.

Krismono, A. \& A. Hardjamulia. 1986. Limnologi: kondisi fisika dan kimia air di Waduk Jatiluhur, Jawa Barat dalam tahun 1983. Buletin Penelitian Perikanan Darat. 5 (1). 100-110.

Krismono, A. \& K. Purnomo. 1991. Pengamatan kualitas air di sekitar lokasi budi daya ikan dalam karamba jaring apung di Teluk Ciganea, Waduk Jatiluhur. Buletin Penelitian Perikanan Darat. 10 (2). 9-22.

Krismono, A. S. N. \& Krismono. 2003. Indikator umbalan dilihat dari aspek kualitas air di perairan Waduk Ir. H. Djuanda, Jatiluhur-Jawa Barat. Jurnal Penelitian Perikanan Indonesia Edisi Sumber Daya dan Penangkapan. 9 (4). 73-85.

Loebis, J \& P. Syariman. 2007. Water resources management for three series reservoir operasional of Citarum River Basin West Java Indonesia. 56. OHS. A176. Manuscript Cascade Citarum. pdf. 8 p. 2 Februari 2007.

Nielsen, L. \& D. L. Johnson. 1985. Fisheries techniques. American Fisheries Society. Bethesda Maryland.

Ryding, S. O. \& W. Rast (eds.). 1989. The control of eutrophication of lake and reservoirs. Man and the Biosphere Series. $314 p$.

Sarnita, A. S. 1981. Pengelolaan perikanan Waduk Jatiluhur. Prosiding Seminar Perikanan Perairan Umum. Pusat Penelitian dan Pengembangan. Departemen Pertanian. Jakarta. P. 211-220. 
Tjahjo, D. W. H. 1986. Ciri-ciri morpologi Waduk Saguling dan beberapa waduk lainnya hubungannya dengan potensi pengembangan perikanan. Buletin Penelitian Perikanan Darat. 5 (1). 47-55.
Walker, W. 1990. Predicting lake water quality. In Olem, H. \& G. Flock (eds.). The Lake and Reservoir Restoration Guidance Manual. 2 nd. Edition. EPA. 440/4-90-006. Prep. Manage. Soc. for U. S. Eviron. Prot. Agency. Washington. D. C. 69-90. 


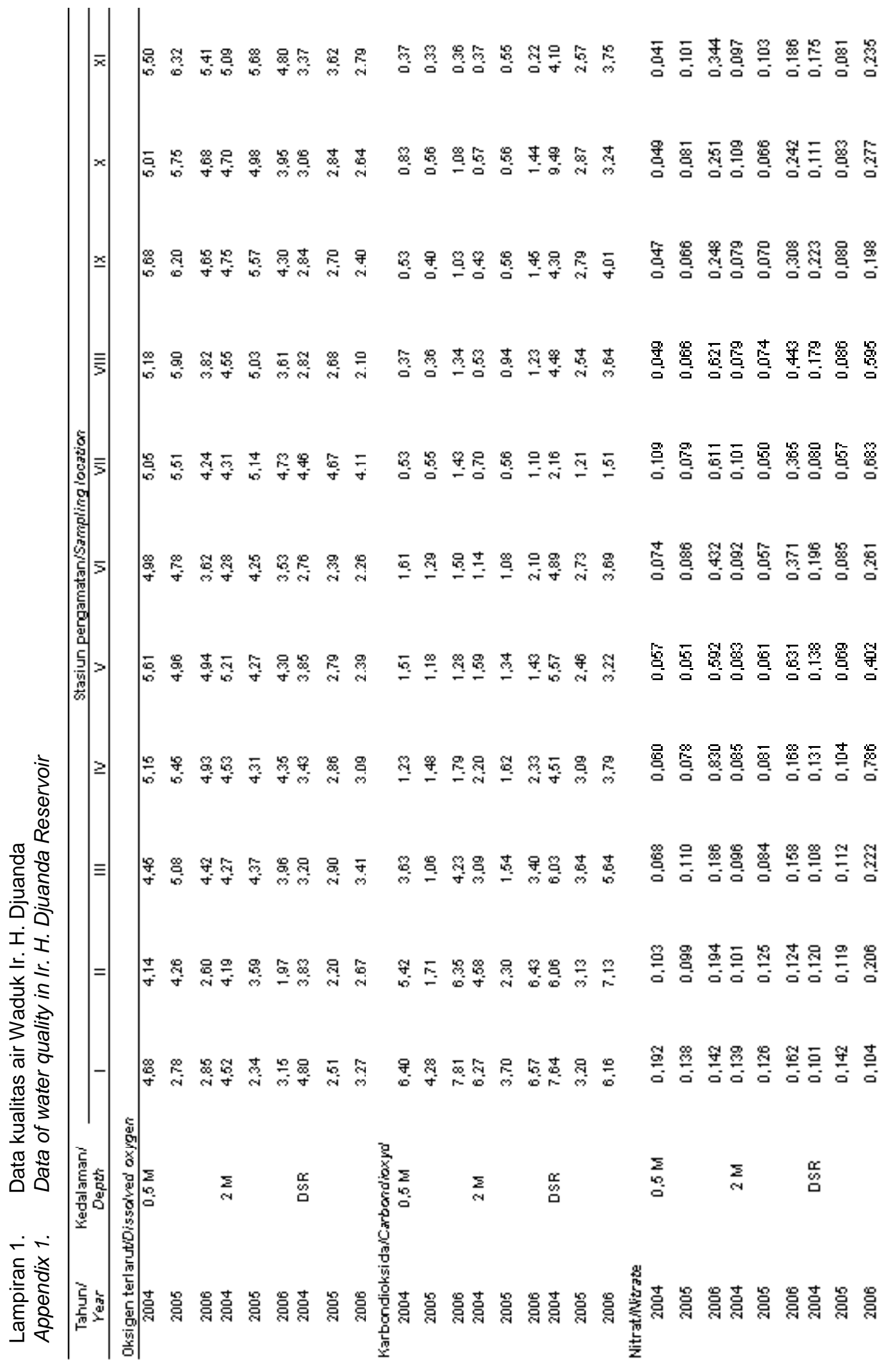




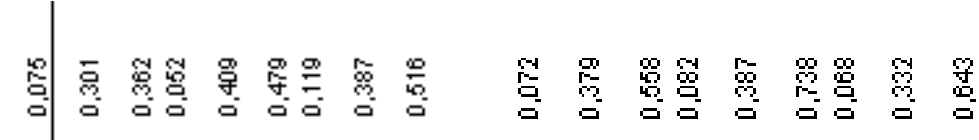

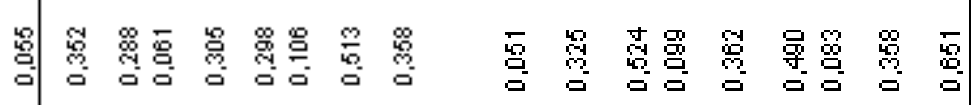

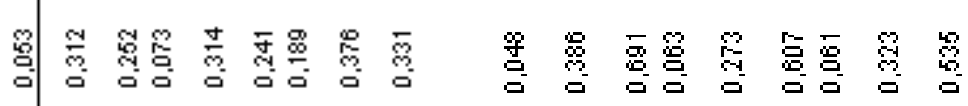

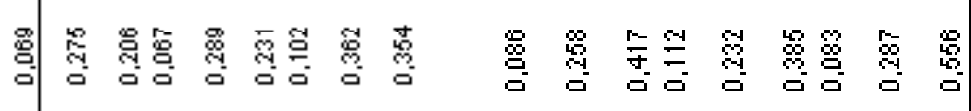

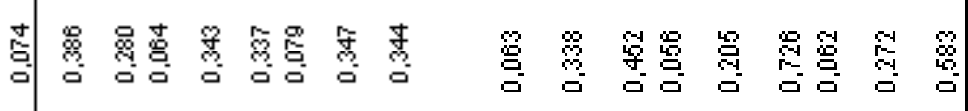

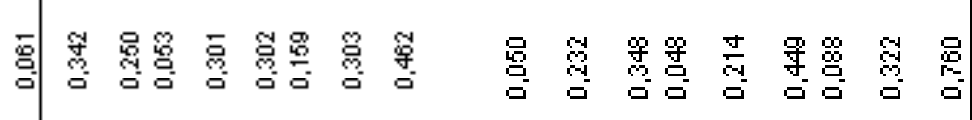

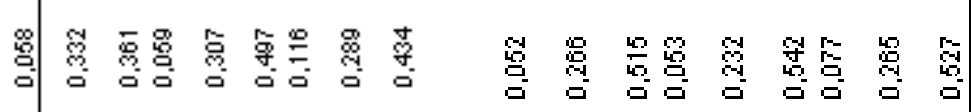

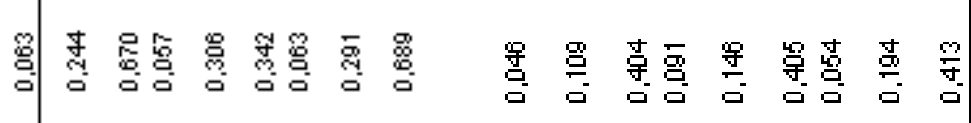

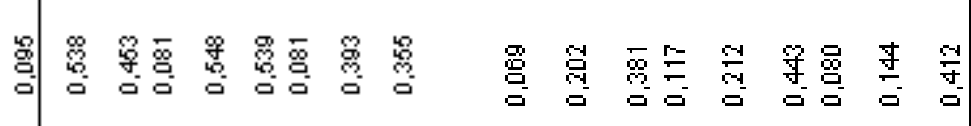

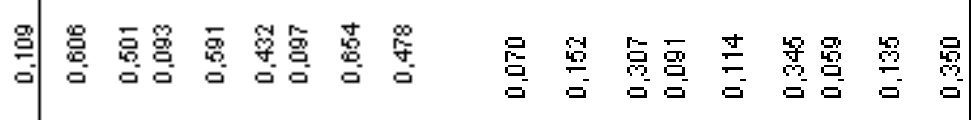

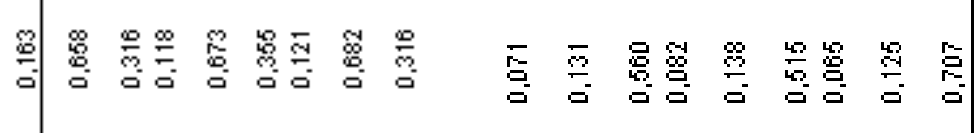

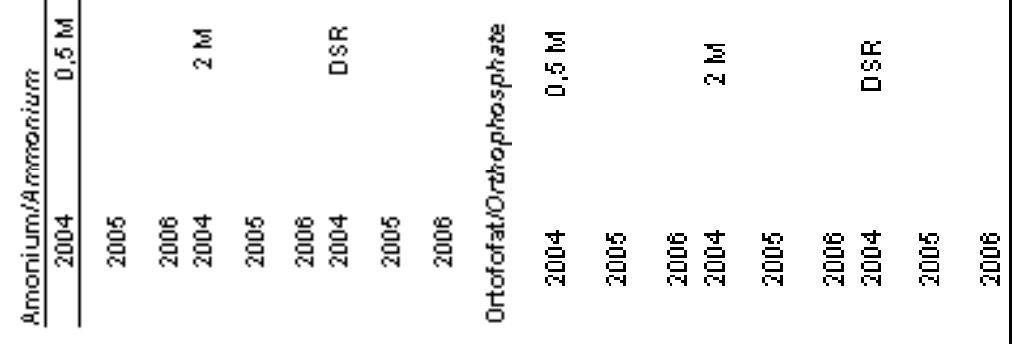

